\title{
Engineered metal nanoparticles in the sub-nanomolar levels kill cancer cells
}

\author{
This article was published in the following Dove Press journal: \\ International Journal of Nanomedicine \\ 18 April 2016 \\ Number of times this article has been viewed
}

\author{
Vitaly Vodyanoy' \\ Yasmine Daniels ${ }^{2}$ \\ Oleg Pustovyy' \\ William A MacCrehan ${ }^{2}$ \\ Shin Muramoto ${ }^{2}$ \\ Gheorghe Stan ${ }^{2}$ \\ 'Department of Anatomy, Physiology \\ and Pharmacology, Auburn University \\ College of Veterinary Medicine, \\ Auburn, AL, ${ }^{2}$ Material Measurement \\ Laboratory, National Institute \\ of Standards and Technology, \\ Gaithersburg, MA, USA
}

Background: Small metal nanoparticles obtained from animal blood were observed to be toxic to cultured cancer cells, whereas noncancerous cells were much less affected. In this work, engineered zinc and copper metal nanoparticles were produced from bulk metal rods by an underwater high-voltage discharge method. The metal nanoparticles were characterized by atomic force microscopy and X-ray photoelectron spectroscopy. The metal nanoparticles, with estimated diameters of $1 \mathrm{~nm}-2 \mathrm{~nm}$, were determined to be more than $85 \%$ nonoxidized. A cell viability assay and high-resolution light microscopy showed that exposure of RG2, cultured rat brain glioma cancer cells, to the zinc and copper nanoparticles resulted in cell morphological changes, including decreased cell adherence, shrinking/rounding, nuclear condensation, and budding from cell bodies. The metal-induced cell injuries were similar to the effects of staurosporine, an active apoptotic reagent. The viability experiments conducted for zinc and copper yielded values of dissociation constants of $0.22 \pm 0.08 \mathrm{nmol} / \mathrm{L}$ (standard error [SE]) and $0.12 \pm 0.02 \mathrm{nmol} / \mathrm{L}(\mathrm{SE})$, respectively. The noncancerous astrocytes were not affected at the same conditions. Because metal nanoparticles were lethal to the cancer cells at sub-nanomolar concentrations, they are potentially important as nanomedicine.

Purpose: Lethal concentrations of synthetic metal nanoparticles reported in the literature are a few orders of magnitude higher than the natural, blood-isolated metal nanoparticles; therefore, in this work, engineered metal nanoparticles were examined to mimic the properties of endogenous metal nanoparticles.

Materials and methods: RG2, rat brain glioma cells CTX TNA2 brain rat astrocytes, obtained from the American Type Culture Collection, high-voltage discharge, atomic force microscope, $\mathrm{X}$-ray photoelectron spectroscopy, high-resolution light microscopy, zeta potential measurements, and 3-[4,5-dimethylthiazol-2-yl]-2,5-diphenyltetrazolium bromide (MTT) assay were used in this work.

Results: Engineered zinc and copper metal nanoparticles of size $1 \mathrm{~nm}-2 \mathrm{~nm}$ were lethal to cultured RG2 glioma cancer cells. Cell death was confirmed by MTT assay, showing that the relative viability of RG2 glioma cells is reduced in a dose-dependent manner at sub-nanomolar concentrations of the nanoparticles. The noncancerous astrocytes were not affected at the same conditions.

Conclusion: The engineered and characterized zinc and copper nanoparticles are potentially significant as biomedicine.

Keywords: nanoparticles, XPS, atomic force, glioma cancer cell, zinc, copper

\section{Introduction}

Small concentrations of protein nucleating centers (PNCs) isolated from animal blood were observed to be toxic to cultured cancer cells. PNCs were composed of metal nanoparticles of size $1 \mathrm{~nm}-2 \mathrm{~nm}$. After incubation with PNCs, the viability of two rat glioma cell lines (F98 and RG2) decreased by 90\% and 75\%, respectively, while that 
A

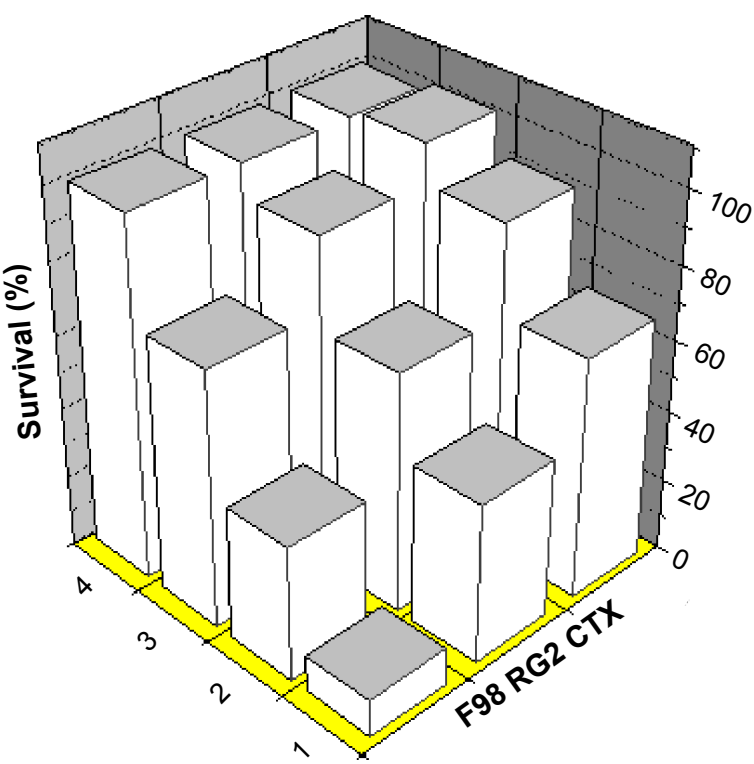

F

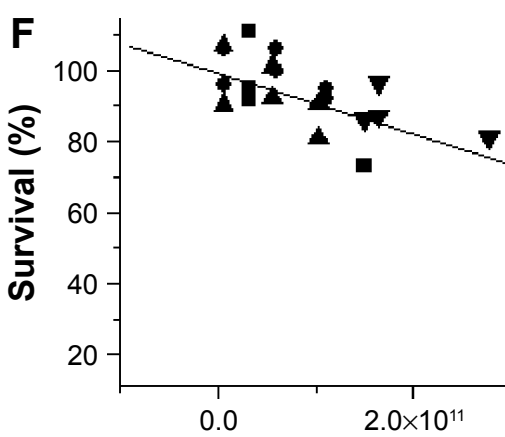

\section{B}

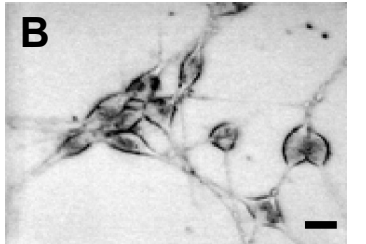

C

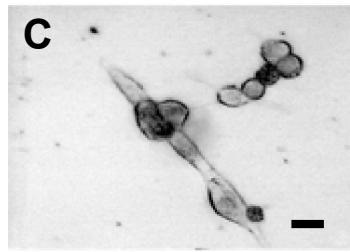

D

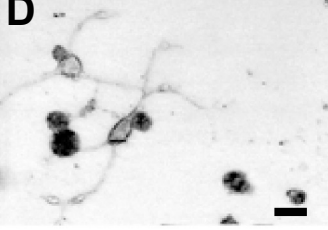

E
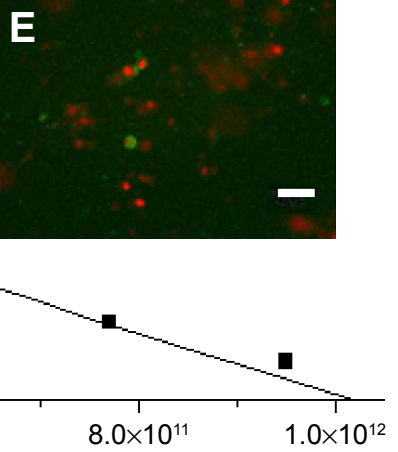

\section{$\mathrm{PNC} / \mathrm{mL}$}

Figure I Effect of PNCs on cell viability.

Notes: (A) Viability of cultured cells after a 20-hour exposure to different concentrations of PNCs (obtained from shark blood). Row I (all expressed in PNCs/mL): I.7×I0"';

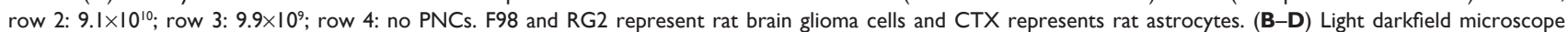
images of rat glioma cells. (B, C) Cells before and after exposure to $7.7 \times 10^{11} \mathrm{PNCs} / \mathrm{mL}$, respectively. (D) Cells after exposure to I.0 $\mu$ M staurosporine. (E) Fluorescence photomicrograph of RG2 glioma cells exposed to $7.7 \times 10^{\prime \prime} \mathrm{PNCs} / \mathrm{mL}$ for 30 minutes and stained with annexin $\mathrm{V}$ and propidium iodide. (F) Viability of cultured RG2 after a 20-hour exposure to different concentrations of PNCs obtained from the blood of the blue shark (square), dog (circle), human (triangle), New Zealand white rabbit (inversed triangle). $R^{2}=0.95 ; P<0.000$ I. Scale bars: $40 \mu \mathrm{mol} / \mathrm{L}$.' Samoylov AM, Samoylova TI, Pustovyy OM, et al. Novel metal clusters isolated from blood are lethal to cancer cells. Cells Tissues Organs. 2005; I79(3): II5-124. Copyright @ 2005 Karger Publishers, Basel, Switzerland.

Abbreviation: PNCs, protein nucleating centers.

of rat astrocytes (CTX) was reduced by only $25 \%$. Total suppression of growth in vitro required $\approx 1 \times 10^{12} \mathrm{PNCs} / \mathrm{mL}$ (ie, a few nmol/L), a concentration smaller than what is typically found in a healthy animal (Figure 1). ${ }^{1}$

Synthetic copper nanoparticles have been found to be toxic to cultured cancer cells, including U937 (human histiocytic lymphoma) and HeLa cells (human cervical cancer origin) at concentrations of $1-500 \mu \mathrm{mol} / \mathrm{L} .^{2-4}$ This suggests cytotoxicity of other metal nanoparticles including zinc, since high concentrations of zinc ions $(\approx 20 \mu \mathrm{mol} / \mathrm{L})$ have previously shown cytotoxicity in a wide range of cultured cancer cells. ${ }^{5-11}$ Lethal concentrations of synthetic metal nanoparticles reported in the literature are a few orders of magnitude higher than the natural, blood-isolated metal nanoparticles; ${ }^{1}$ therefore, in this work, engineered metal nanoparticles were examined to mimic properties of endogenous metal nanoparticles.

\section{Materials and methods Metal nanoparticle preparation}

Engineered zinc and copper nanoparticles were prepared using high-voltage discharge method from bulk metal rods at alternating current (AC) 15,000 V for 1 hour ${ }^{12,13}$ (Supplementary materials).

\section{Cell culture}

RG2, F98 (rat brain glioma lines), and CTX TNA2 (brain, rat astrocytes transfected with SV40) were obtained from the 
American Type Culture Collection (ATCC) and maintained as recommended by ATCC.

\section{Cell viability assay}

3-[4,5-dimethylthiazol-2-yl]-2,5-diphenyl tetrazolium bromide (MTT) assay ${ }^{14}$ was used to measure cell viability (Supplementary materials). Eight experiments with zinc nanoparticles and five experiments with copper nanoparticles and RG2 cells were performed. Sixteen control experiments with zinc and copper nanoparticles and CTX astrocytes were performed. Experiments tested cells in six conditions: untreated cells, metal nanoparticles at four different subnanomolar concentrations, or $1 \mu \mathrm{mol} / \mathrm{L}$ of staurosporine added to cells. Each condition was repeated six times. Results were presented as mean values for each condition \pm standard error (SE). The concentration of metal nanoparticles is much lower than that found in the animal blood. ${ }^{1}$

\section{Atomic force microscopic images}

Images of metal nanoparticles were taken by Bruker MultiMode 8 (Santa Barbara, CA, USA) atomic force microscope in tapping (intermittent-contact) mode. Monolayers of zinc and copper nanoparticles were prepared on a mica substrate. Size distributions of nanoparticles were measured in five independent scans over different areas (Supplementary materials).

\section{X-ray photoelectron spectroscopy}

The Kratos Axis Ultra delay-line detector instrument in hybrid mode using a monochromatic $\mathrm{Al} \mathrm{K} \alpha 1,2 \mathrm{X}$-ray source ( $h v=1,486.6 \mathrm{eV}$ ) was used for X-ray photoelectron spectroscopy (XPS). Zinc and copper nanoparticles were analyzed in a water suspension on a silicon wafer (Supplementary materials).

\section{Light microscopy}

Darkfield light microscopic images were produced by a highresolution microscope system ${ }^{15}$ (Supplementary materials).

\section{Zeta potential}

Zeta potentials of the nanoparticles in water suspension were determined with a Zetasizer Nano ZSP (Malvern Instruments, Worcestershire, UK) using the laser Doppler velocimetry technique. The results of six sequential runs were averaged (Supplementary materials).

\section{Results}

Figure 2 shows the physical properties of $\mathrm{Zn}$ and $\mathrm{Cu}$ nanoparticles prepared by high-voltage discharge. Atomic force microscopy revealed the size distributions of $\mathrm{Zn}$ and $\mathrm{Cu}$ nanoparticles, with average diameters of $1.2 \pm 0.3 \mathrm{~nm}$ and $2.1 \pm 0.6 \mathrm{~nm}$, respectively (Figure 2A and B). Histograms (Figure 2C and D) represent distributions with relatively high peaks around average values (their standard deviations [SDs] were calculated from the bell distributions around the peaks) and tails up to $6 \mathrm{~nm}$. The nanoparticles were homogenously distributed with polydispersity indexes of 0.062 and 0.082 for zinc and copper, respectively.

Figure 2E and $F$ shows XPS high-resolution 2p3/2 spectra for metal and metal oxide species: $93.9 \% \pm 3.4 \%$ and $5.9 \% \pm 3.7 \%(\mathrm{Zn}$ and $\mathrm{ZnO})$ and $85.8 \% \pm 4.1 \%$ and $14.2 \% \pm 4.1 \%$ $(\mathrm{Cu}$ and $\mathrm{CuO})$. These data indicate that more than $85 \%$ of metal atoms were not oxidized.

Zeta potentials for zinc and copper nanoparticles in water suspension were determined as $\zeta_{\mathrm{Zn}}=-15.4 \pm 0.8$ (SD) $\mathrm{mV}$ and $\zeta_{\mathrm{Cu}}=-17.4 \pm 1.7(\mathrm{SD}) \mathrm{mV}$.

Following incubation with zinc nanoparticles for 20 hours, cells displayed morphological features consistent with cell death, including a decrease in adherence, shrinking/ rounding, nuclear condensation, and budding from cell bodies (Figure 3). Zn-induced cell injury was similar to the effects of $1 \mu \mathrm{mol} / \mathrm{L}$ staurosporine, an effective apoptotic reagent. ${ }^{16}$

Cell death was confirmed by MTT assay, showing that the relative viability of $\mathrm{RG} 2$ glioma cells is reduced in a dose-dependent manner when added zinc nanoparticle concentrations increased from $0.05 \mathrm{nmol} / \mathrm{L}$ to $0.3 \mathrm{nmol} / \mathrm{L}$, reducing the cell viability by $\approx 60 \%$ (Figure $4 \mathrm{~A}$ ). This reduction in viability compares well to that of $1 \mu \mathrm{mol} / \mathrm{L}$ staurosporine (Figure 4A; treatment 5). Assuming that cell death is proportional to the number of bound metal nanoparticles, the ratio of relative number of dead $(\mathrm{Y})$ and alive $(1-\mathrm{Y})$ cells can be presented by the Hill presentation of binding,

$$
\log \frac{\mathrm{Y}}{1-\mathrm{Y}}=\log \frac{1-V}{V}=\log \mathrm{K}_{\mathrm{b}}+\operatorname{nlog}[\mathrm{M}]
$$

where $\mathrm{V}$ is the relative cell viability measured by the cell viability assay, $n$ is the valence of binding, $K_{b}=1 / K_{d}, K_{b}$, and $\mathrm{K}_{\mathrm{d}}$ are the association and dissociation constants, and $[\mathrm{M}]$ is the nanoparticle concentration. Figure $4 \mathrm{~B}$ shows the ratio Y/1-Y vs concentration zinc nanoparticles. Similar results were obtained with copper nanoparticles (Figure 4C and D). The values of $\mathrm{K}_{\mathrm{d}}$ and $\mathrm{n}$ obtained for zinc by viability experiments were $0.22 \pm 0.08 \mathrm{nmol} / \mathrm{L}(\mathrm{SE})$ and $1.45 \pm 0.17(\mathrm{SE})$, respectively. Likewise, the values of $\mathrm{K}_{\mathrm{d}}$ and $\mathrm{n}$ obtained for copper nanoparticles were $0.12 \pm 0.02 \mathrm{nmol} / \mathrm{L}(\mathrm{SE})$ and $1.09 \pm 0.1$ (SE), respectively. $\mathrm{IC}_{50}$ values for RG2 cells were $0.27 \pm 0.1 \mathrm{nmol} / \mathrm{L}$ and $0.26 \pm 0.1 \mathrm{nmol} / \mathrm{L}(\mathrm{SD})$, for $\mathrm{Zn}$ and 
A

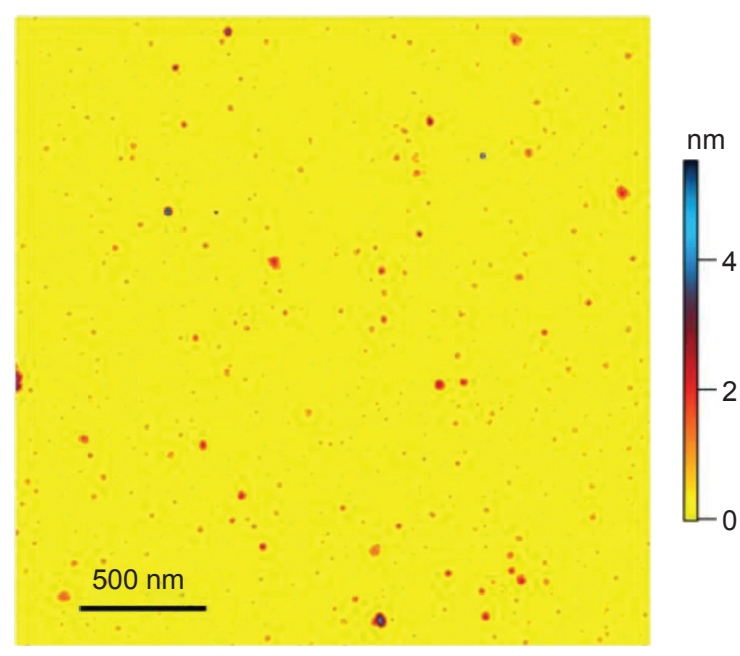

C
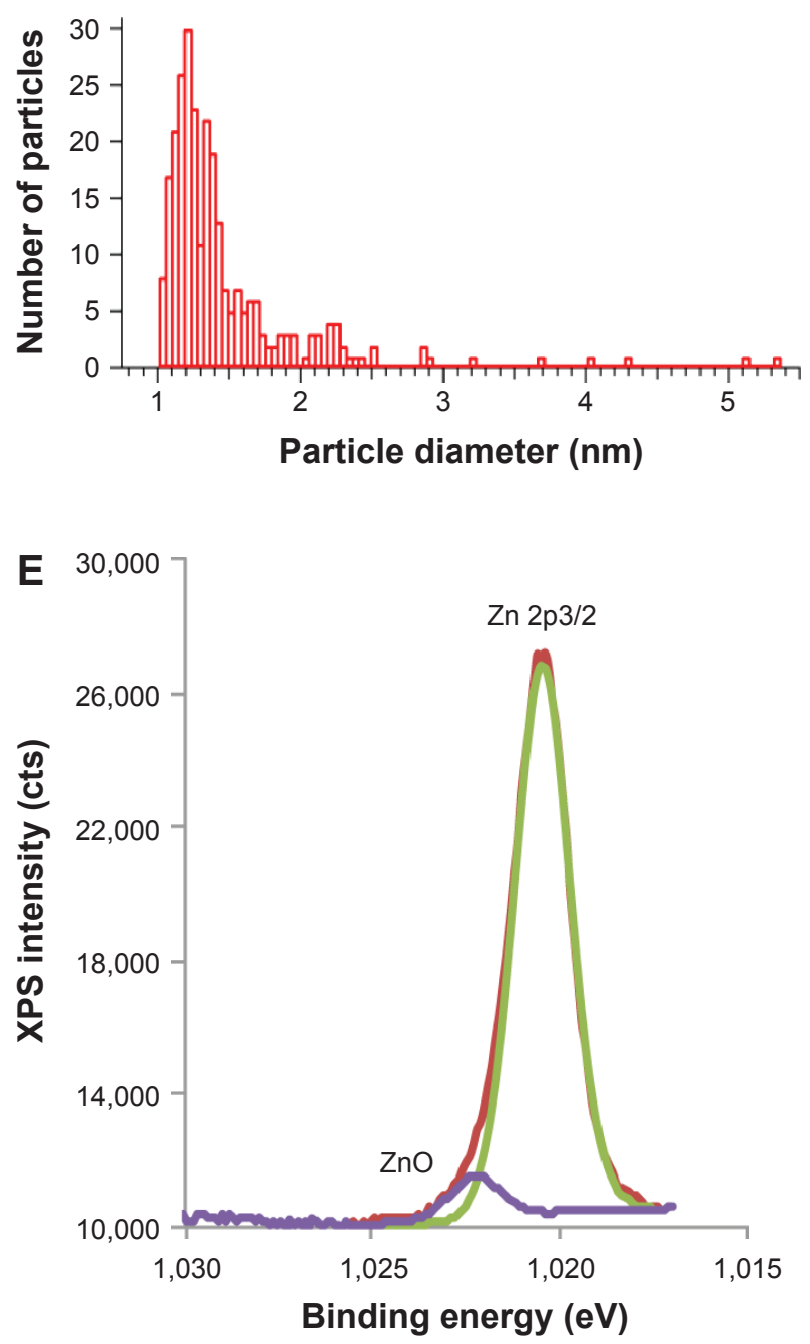

B

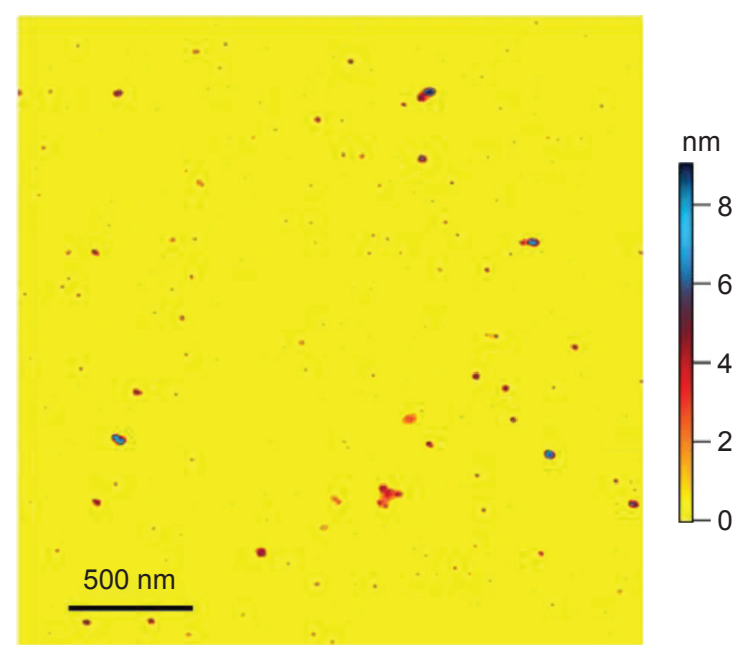

D
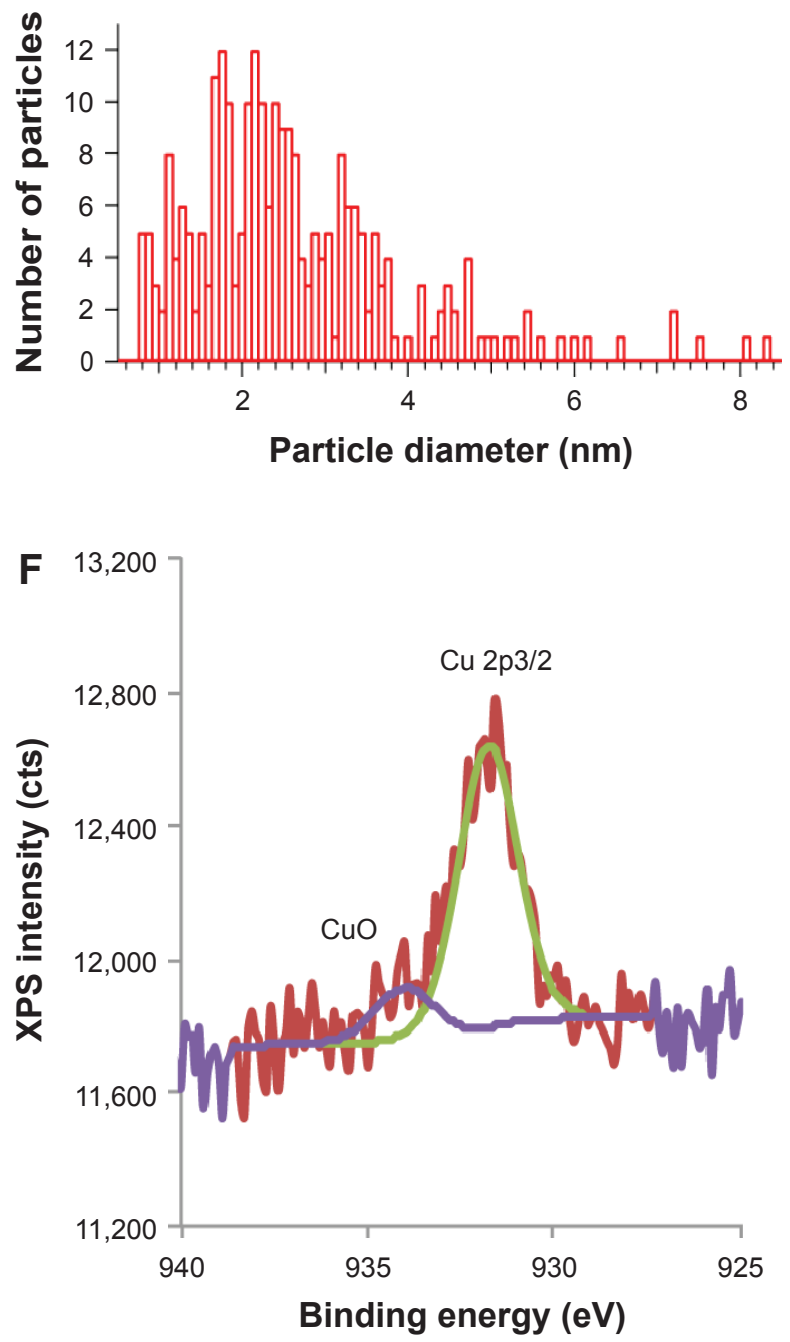

Figure 2 Zinc and copper metal nanoparticles.

Notes: Atomic force microscope images ( $\mathbf{A}$ and $\mathbf{B})$, size distributions $(\mathbf{C}$ and $\mathbf{D})$, and XPS spectra (E and $\mathbf{F})$ of zinc and copper nanoparticles, respectively. (A) 0.0 I\% zinc nanoparticles on mica. A total of 270 nanoparticles with a height of above I nm were detected over a $2.5 \mu \mathrm{m}^{2}$ area. (B) A total of $0.01 \%$ copper nanoparticles on mica; 257 nanoparticles with a height of above $0.75 \mathrm{~nm}$ were detected over a $2.5 \mu \mathrm{m}^{2}$ area. (E and F) High-resolution XPS of Zn $2 \mathrm{p} 3 / 2$ and Cu $2 \mathrm{p} 3 / 2$ lines, showing the relative concentration of oxidized metal species.

Abbreviation: XPS, X-ray photoelectron spectroscopy. 

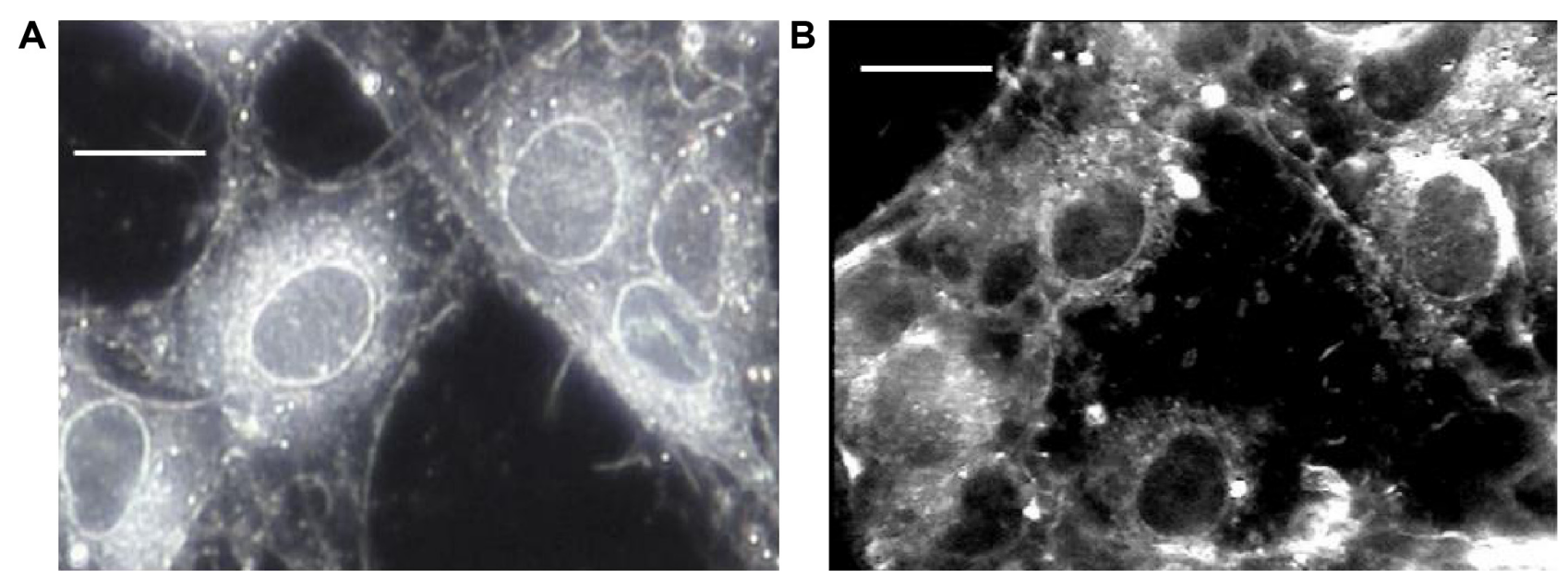

Figure 3 Light darkfield images of RG2 glioma cells before (A) and after (B) exposure to $5 \mathrm{nmol} / \mathrm{L}$ of zinc nanoparticles (Bar, $10 \mu \mathrm{m}$ ).
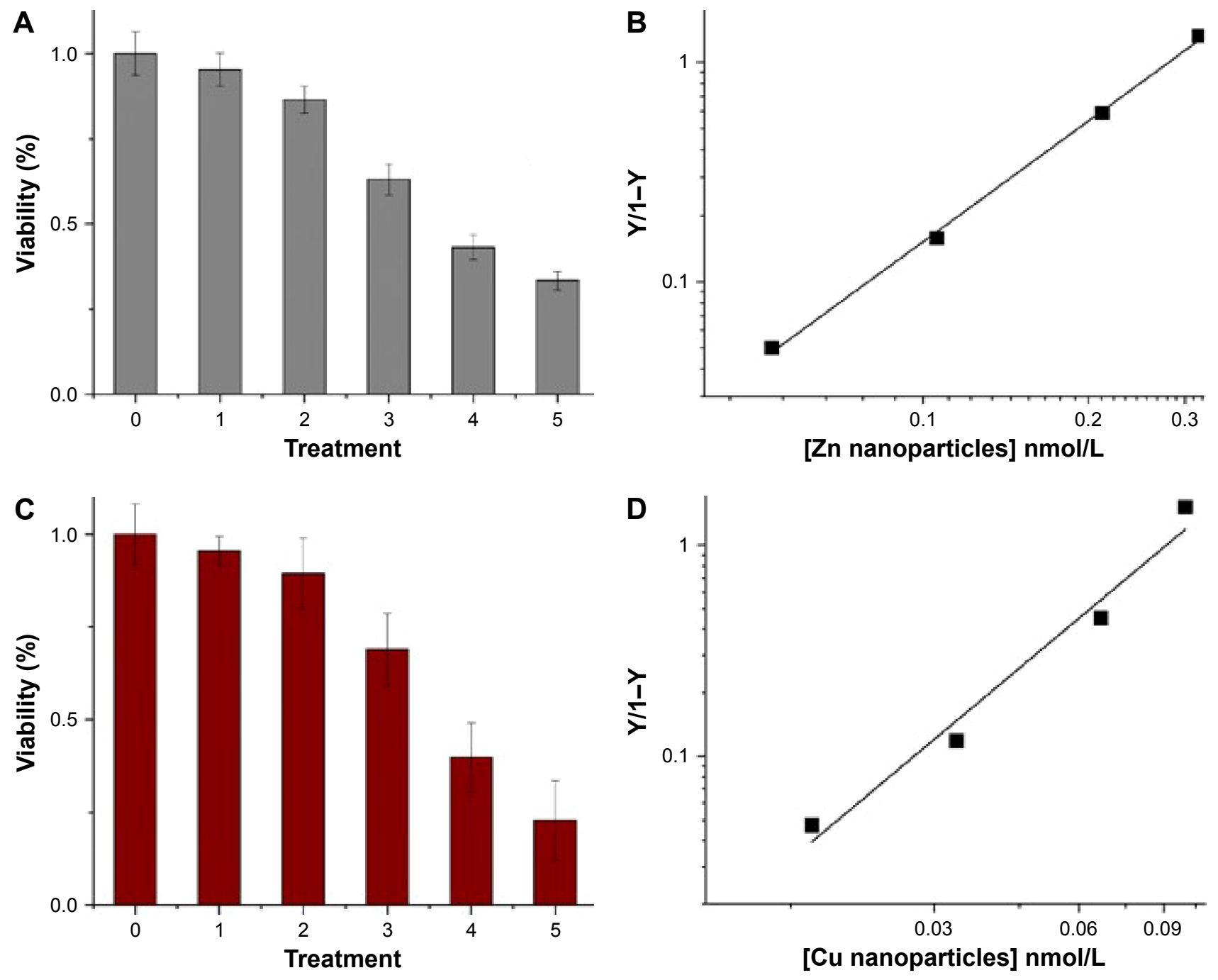

Figure 4 (Continued) 

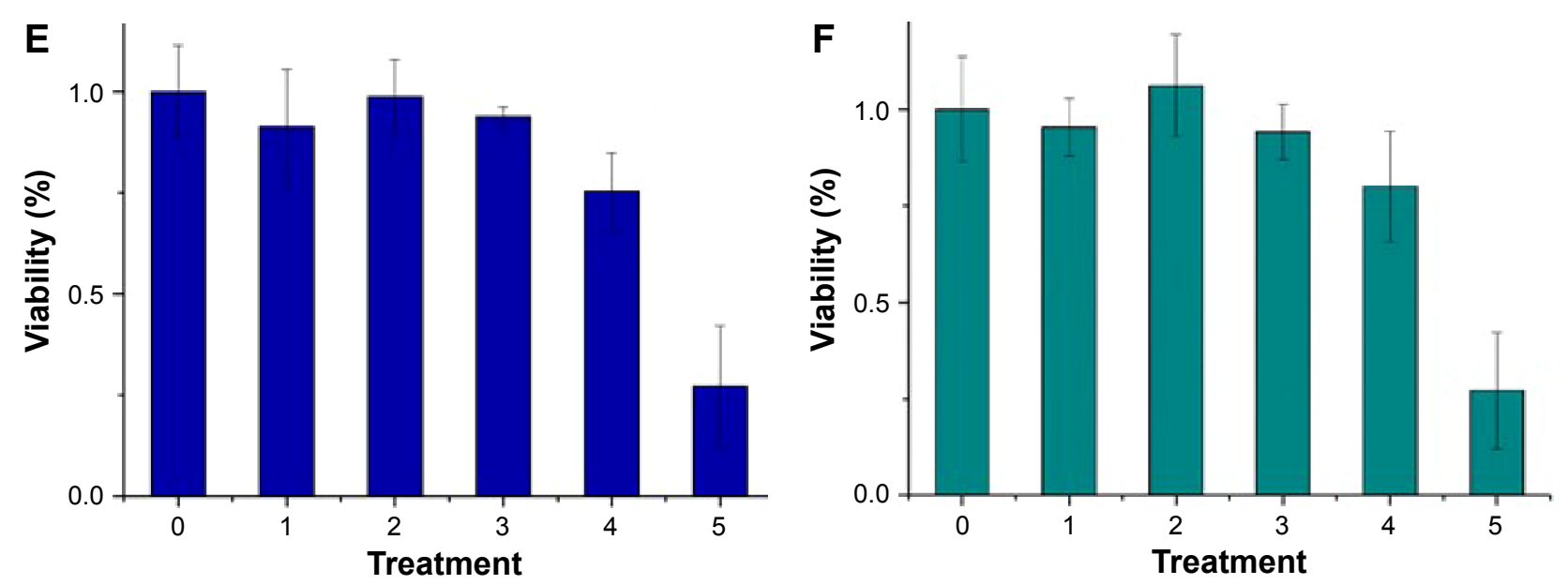

Figure 4 Viability and mortality of glioma cancer cells treated with metal nanoparticles (error bars are standard deviations).

Notes: (A) Viability of glioma cells at six experimental conditions: 0 , no treatment; I-4, zinc nanoparticles (all expressed in nmol/L) $0.053,0.106,0.212,0.3$ I 8 , respectively; 5, I $\mu \mathrm{mol} / \mathrm{L}$ of staurosporine. (B) Hill presentation of glioma cell mortality caused by zinc nanoparticles. (C) Viability of glioma cells at six experimental conditions: 0 , no treatment; I-4, copper nanoparticles (all expressed in nmol/L) $0.017,0.033,0.066,0.1$, respectively; $5, I \mu$ mol/L of staurosporine. (D) Hill presentation of glioma cell mortality caused by copper nanoparticles. (E) Viability of astrocytes at six experimental conditions: 0 , no treatment; I-4, zinc nanoparticles (all expressed in nmol/L) $0.053,0.106,0.212$, 0.318 , respectively; $5,1 \mu \mathrm{mol} / \mathrm{L}$ of staurosporine. (F) Viability of astrocytes at six experimental conditions: 0 , no treatment; I-4, copper nanoparticles (all expressed in nmol/L) $0.017,0.033,0.066,0.1$, respectively; $5,1 \mu \mathrm{mol} / \mathrm{L}$ of staurosporine.

$\mathrm{Cu}$, respectively. Within the margin of error, the noncancerous astrocytes were not affected at the same conditions (Figure 4E and F).

\section{Discussion}

Small, engineered metal nanoparticles of zinc and copper examined in this work were lethal to RG2 cultured cancer cells at sub-nanomolar concentrations. The results obtained are consistent with those with the natural metal nanoparticles isolated from animal blood. ${ }^{1}$ Copper nanoparticles of 4-5 nm in size caused degradation of DNA molecules in U937 and HeLa cells at concentrations of $100 \mu \mathrm{mol} / \mathrm{L}-500 \mu \mathrm{mol} / \mathrm{L}$. The apparent dissociation constant for copper nanoparticles, $32 \mu \mathrm{mol} / \mathrm{L},{ }^{3}$ was approximately 25,000 -fold larger than that found in the present work. ${ }^{3}$ Prior studies revealed that bigger $\mathrm{CuO}$ nanoparticles $(\approx 20 \mathrm{~nm})$ ranging from 1 to $27 \mu \mathrm{mol} / \mathrm{L}$ caused HeLa cell degradation ${ }^{4}$; however, synthetic copper nanoparticles (1 nm-2 nm) encapsulated in water soluble polymers also reduced HeLa cell viability by $70 \%$ at $\approx 1 \mu \mathrm{mol} / \mathrm{L}$. ${ }^{2}$ Zinc and copper nanoparticles examined in our work proved to be lethal to cancer cells at concentrations of a few orders of magnitude smaller than those found in the literature, while noncancerous cells were not affected.

The only nanoparticle that presented sub-nanomolar efficiency against cancer is iron oxide with a low $\mathrm{K}_{\mathrm{d}}$ value of $0.2 \mathrm{nmol} / \mathrm{M} \cdot{ }^{17}$

We speculate that small, uncharged nanoparticles of size $1 \mathrm{~nm}-2 \mathrm{~nm}$ can efficiently penetrate through the external and nuclear membranes and create aggregates with some protein or nucleic acids. Aggregates inside RG2 glioma cells increased up to $\approx 100 \mathrm{~nm}$ when the glioma cells were exposed to natural metal nanoparticles. ${ }^{1}$ Large aggregates are recognized as foreign particles and expelled by exocytosis. ${ }^{18}$ Perhaps when many aggregate particles leave the cell, the external cell membrane depletes causing nucleus budding and cell death. The morphological changes observed in cells exposed to metal nanoparticles are similar to those of the cells treated with staurosporine, a known apoptotic agent. ${ }^{16}$ The apoptotic death of cancer cells caused by copper nanoparticles was also reported. ${ }^{2,3}$ It was found that surface charge is a major determinant of how metal nanoparticles impact cellular processes. The charged nanoparticles induce cell death through apoptosis and neutral nanoparticles lead to necrosis. ${ }^{19}$ Zeta potentials of zinc and copper nanoparticles indicate that they are electrically charged. Therefore, we believe that the cell death in the present report has an apoptotic modality. Further research is needed to determine the exact mechanism of cell death.

\section{Conclusion}

Zinc and copper metal nanoparticles of size $1 \mathrm{~nm}-2 \mathrm{~nm}$ produced by the underwater electrical discharge method were lethal to the cultured RG2 glioma cancer cells, while noncancerous astrocyte cells were not affected. These nanoparticles are potentially significant as nanomedicine.

\section{Acknowledgments}

The work was funded by National Institute of Standards and Technology grant number 70 NANB14H324. The authors thank M Mansour and A David for useful discussion. 


\section{Disclosure}

The authors report no conflicts of interest in this work. Certain commercial equipment, instruments, or materials are identified in this paper to specify the experimental procedure adequately. Such identification is not intended to imply recommendation or endorsement by the National Institute of Standards and Technology nor is it intended to imply that the materials or equipment identified are necessarily the best available for the purpose.

\section{References}

1. Samoylov AM, Samoylova TI, Pustovyy OM, et al. Novel metal clusters isolated from blood are lethal to cancer cells. Cells Tissues Organs. 2005;179(3):115-124.

2. Ghosh R, Goswami U, Ghosh SS, Paul A, Chattopadhyay A. Synergistic anticancer activity of fluorescent copper nanoclusters and cisplatin delivered through a hydrogel nanocarrier. ACS Appl Mater Interfaces. 2015;7(1):209-222.

3. Jose GP, Santra S, Mandal SK, Sengupta TK. Singlet oxygen mediated DNA degradation by copper nanoparticles: potential towards cytotoxic effect on cancer cells. J Nanobiotechnol. 2011;9:9.

4. Studer AM, Limbach LK, Van Duc L, et al. Nanoparticle cytotoxicity depends on intracellular solubility: comparison of stabilized copper metal and degradable copper oxide nanoparticles. Toxicol Lett. 2010; 197(3):169-174.

5. Bastow M, Kriedt CL, Baldassare J, Shah M, Klein C. Zinc is a potential therapeutic for chemoresistant ovarian cancer. J Exp Ther Oncol. 2011;9(3):175-181.

6. Kriedt CL, Baldassare J, Shah M, Klein C. Zinc functions as a cytotoxic agent for prostate cancer cells independent of culture and growth conditions. J Exp Ther Oncol. 2010;8(4):287-295.

7. Shah MR, Kriedt CL, Lents NH, et al. Direct intra-tumoral injection of zinc-acetate halts tumor growth in a xenograft model of prostate cancer. J Exp Clin Cancer Res. 2009;28(1):84.
8. Uzzo RG, Leavis $P$, Hatch W, et al. Zinc inhibits nuclear factor-kappa B activation and sensitizes prostate cancer cells to cytotoxic agents. Clin Cancer Res. 2002;8(11):3579-3583.

9. Bae SN, Kim J, Lee YS, Kim JD, Kim MY, Park LO. Cytotoxic effect of zinc-citrate compound on choriocarcinoma cell lines. Placenta. 2007; 28(1):22-30.

10. Hashemi M, Ghavami S, Eshraghi M, Booy EP, Los M. Cytotoxic effects of intra and extracellular zinc chelation on human breast cancer cells. Eur J Pharmacol. 2007;557(1):9-19.

11. Mathew ME, Mohan JC, Manzoor K, Nair SV, Tamura H, Jayakumar R. Folate conjugated carboxymethyl chitosan-manganese doped zinc sulphide nanoparticles for targeted drug delivery and imaging of cancer cells. Carbohyd Polym. 2010;80(2):442-448.

12. Kruyt HR. Colloid Science. Vol VI. New York: Elsevier; 1952.

13. Tokushige M, Nishikiori T, Ito Y. Plasma-induced cathodic discharge electrolysis to form various metal/alloy nanoparticles. Russ J Electrochem. 2010;46(6):619-626.

14. Berridge MV, Herst PM, Tan AS. Tetrazolium dyes as tools in cell biology: new insights into their cellular reduction. Biotechnol Ann Rev. 2005; 11:127-152.

15. Vainrub A, Pustovyy O, Vodyanoy V. Resolution of $90 \mathrm{~nm}$ (lambda/5) in an optical transmission microscope with an annular condenser. $O p t$ Lett. 2006;31(19):2855-2857.

16. Xue L-Y, Chiu S-M, Oleinick NL. Staurosporine-induced death of MCF-7 human breast cancer cells: a distinction between caspase-3dependent steps of apoptosis and the critical lethal lesions. Exp Cell Res. 2003;283:135-145.

17. Ndong C, Tate JA, Kett WC, et al. Tumor cell targeting by iron oxide nanoparticles is dominated by different factors in vitro versus in vivo. PLoS One. 2015;10(2):e0115636.

18. Kohane DS. Microparticles and nanoparticles for drug delivery. Biotechnol Bioeng. 2007;96(2):203-209.

19. Schaeublin NM, Braydich-Stolle LK, Schrand AM, et al. Surface charge of gold nanoparticles mediates mechanism of toxicity. Nanoscale. 2011; $3(2): 410-420$. 


\section{Supplementary materials Metal nanoparticles}

Metal nanoparticles were produced by the modification as per the method described. ${ }^{1,2}$ The system consists of a water container and a high-voltage generator connected with two metal electrodes submerged in water. By controlling the voltage and distance between the electrodes, the plasma created under water produces a very fine dispersion of metal into nanoparticles (Figure S1).

Two metal electrodes (99.9999\%; Alfa Aesar, Haverhill, MA, USA) of $2 \mathrm{~mm}$ diameter are positioned in a large Pyrex jar $1 \mathrm{~mm}$ below the gas-water interface at a distance of $\approx 0.5 \mathrm{~cm}$. A total of $750 \mathrm{~mL}$ of liquid chromatography - mass spectrometry ( LC-MS) grade water (Omnisolv, Charlotte, NC, USA) is used in this procedure (Figure S1). The jar filled with nitrogen is placed in the water bath with running water to prevent overheating. An AC voltage of 15,000 volts is applied to electrodes and the electric discharge is sustained for 1 hour. The water suspension is collected in $1 \mathrm{~L}$ glass beaker and placed in the refrigerator for 12 hours to allow large metal particles to sediment. Then the suspended particles are separated from the sediment and subjected to centrifugation at $15,000 \times g$ for 2 hours at $25^{\circ} \mathrm{C}$. After centrifugation, the pellet is discarded and the supernatant is subjected to further centrifugations to produce fractions of nanoparticles enriched in particles of particular sizes. The centrifuge speed and time to separate nanoparticles by size are estimated with Stock's equation. The particle suspensions are analyzed similarly to that described in the work by Samoylov et al. ${ }^{3}$ The total concentration of metal in suspension was measured by atomic absorption spectra (GTW Analytical Services, Memphis, TN, USA), and the size and the number of particles are determined by atomic force microscopy.

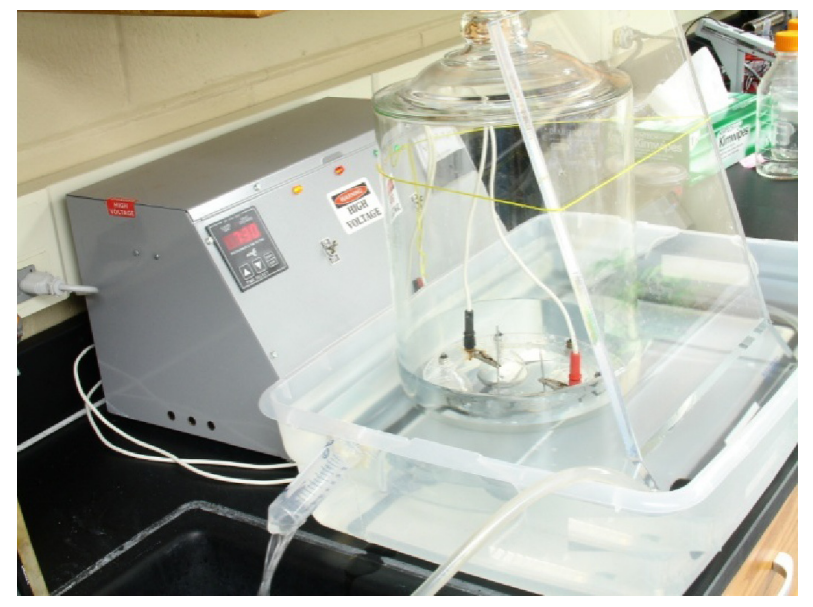

Figure SI Setup for the production of metal nanoparticles by the underwater spark at high voltage.

\section{Microscopy}

The illumination optical system ${ }^{4}$ with a high-aperture cardioid annular condenser has been used in this work. The system produces a highly oblique hollow cone of light (numerical aperture $[\mathrm{NA}]=1.2-1.4$ ). The illumination system is positioned in an Olympus BX51 microscope by replacing a regular condenser. The illumination system is connected with a light source (EXFO120; Photonic Solution Ltd, Edinburgh, UK) by a liquid light guide. The objective used for this work is an infinity-corrected objective HCX PL APO $100 / 1.40-0.70$, oil, iris from Leica. The image is magnified by a zoom intermediate lens $(2 \times-\mathrm{U}-\mathrm{CA}$, Olympus Corporation, Shinjuku, Tokyo City, Tokyo, Japan), a homebuilt 40× relay lens, and captured by a Sony MCC-500MD video and a Dimension 8200 Dell computer. The microscope is placed on a vibration-isolated platform (manufactured by TMC, Peabody, MA, USA).

\section{Atomic force microscopic images}

The images of metal nanoparticles were taken by Bruker MultiMode 8 (Santa Barbara, CA, USA) atomic force microscope (AFM) in tapping ${ }^{\circledR}$ (intermittent-contact) mode, using PointProbe ${ }^{\circledR}$ Plus SEIKO microscopes - Non-Contact/Tapping Mode High Force Constant(PPP-SEIH) made by Nanosensors ${ }^{\mathrm{TM}}$ (Neuchatel, Switzerland) AFM probes; the nominal values specified by the vendor for the force constant and resonance frequency of these probes are $15 \mathrm{~N} / \mathrm{m}$ and $130 \mathrm{kHz}$, respectively. The AFM imaging was used to measure the size distribution of particles. Monolayers of zinc and copper nanoparticles were prepared on a mica substrate for all measurements by adding small amount of $0.01 \%$ nanoparticles solution on freshly cleaved mica surfaces.

\section{XPS spectra}

$\mathrm{X}$-ray photoelectron spectroscopy (XPS) was used to make quantitative spectroscopic measurements of the elemental composition of the nanoparticles' surfaces. The Kratos Axis Ultra delay-line detector instrument in hybrid mode using a monochromatic $\mathrm{Al} \mathrm{K} \alpha 1,2 \mathrm{X}$-ray source $(h v=1,486.6 \mathrm{eV})$ was used. High-resolution spectra of Zn 2p (1,017-1,057 eV) and $\mathrm{Cu} 2 \mathrm{p}(925-965 \mathrm{eV})$ were acquired using a pass energy of $40 \mathrm{eV}$ with an energy resolution of $0.1 \mathrm{eV}$. Zinc and copper nanoparticles were analyzed in a water suspension on a silicon wafer.

\section{Cell viability assay}

A cell viability assay ${ }^{5}$ quantitatively determined the effect of metal nanoparticles on cell viability. Cells were plated in D5648 media (Sigma 96-well polystyrene plates) at a density 
of $3 \times 10^{3}$ cells/well. At 24 hours after plating, the medium was replaced with Dulbecco's Modified Eagle's Medium (100 $\mu \mathrm{L} /$ well) containing either $1 \mu \mathrm{mol} / \mathrm{L}$ staurosporine or zinc or copper nanoparticles with various concentrations $(0.05-0.3 \mathrm{~nm})$. At 20 hours after treatment, a $20 \mu \mathrm{L}$ aliquot of tetrazolium salt (3-[4,5-dimethylthiazol-2-yl]-2,5-diphenyl tetrazolium bromide; MTT, $5 \mathrm{mg} / \mathrm{mL}$ in phosphate buffer solution $[\mathrm{PBS}]$ ) was added to each well, and the cells were incubated for 4 hours at $37^{\circ} \mathrm{C}$. MTT was reduced in metabolically active cells to form purple formazan crystals that were subsequently dissolved in dimethyl sulfoxide and quantified by a plate reader (Bio-Rad, Hercules, CA, USA). The dye is cleared to a colored product by the activity of NAD $(\mathrm{P})$ $\mathrm{H}$-dependent dehydrogenase enzymes, and this indicates the level of energy metabolism in cells. The color development (yellow to blue) is proportional to the number of metabolically active cells. The analysis was carried out with Origin: Data Analysis and Graphing Software (OriginLab).

\section{Binding equations}

The purpose of this section is to present a quantitative description of binding by using known binding equations and to describe the interaction of metal nanoparticles (M) and target molecules in cells (T) and resulting complexes in terms of binding parameters. The applicability of the binding equations to the $\mathrm{M}-\mathrm{T}$ system is not trivial and special considerations are required. The reaction between $\mathrm{M}$ and $\mathrm{T}$ can be schematically presented as follows:

$$
\mathrm{nM}+\mathrm{T} \leftrightarrows \mathrm{TM}_{\mathrm{n}}
$$

where $\mathrm{n}$ is the number of metal nanoparticles bound to a single binding site on the target molecule. We accept that one, two, or more binding sites on the target molecule can be involved in the binding of one metal nanoparticle depending on the mono-, bi-, or multivalency of binding. Then n might be equal to $1,0.5$, or $1 / \mathrm{k}$, where $\mathrm{k}$ is the valence of binding.

The association binding constant $\left(\mathrm{K}_{\mathrm{b}}\right)$ for this reaction can be defined using the mass action law. ${ }^{6,7}$

$$
\mathrm{K}_{\mathrm{b}}=\frac{T M_{n}}{\left([\mathrm{~T}][\mathrm{M}]^{\mathrm{n}}\right)}
$$

If we neglect the number of target molecules bound to nonspecific molecules, then the total number of the target-molecule binding sites $\left(\mathrm{C}_{\mathrm{T}}\right)$ is composed of the free binding sites and the sites bound to the metal nanoparticles:

$$
\mathrm{C}_{\mathrm{T}}=\mathrm{T}+\mathrm{TM}_{\mathrm{n}}
$$

Combining Equations S2 and S3, we can determine the fraction of the target-molecule binding sites occupied by the metal nanoparticles:

$$
\mathrm{Y}=\frac{\mathrm{TM}_{\mathrm{n}}}{\mathrm{C}_{\mathrm{T}}}=\frac{\mathrm{K}_{\mathrm{b}}[\mathrm{M}]^{\mathrm{n}}}{1+\mathrm{K}_{\mathrm{b}}[\mathrm{M}]^{\mathrm{n}}}
$$

The ratio of occupied and free target-molecule binding sites can be defined as follows:

$$
\frac{\mathrm{Y}}{1-\mathrm{Y}}=\mathrm{K}_{\mathrm{b}}[\mathrm{M}]^{\mathrm{n}}
$$

Taking the logarithm of both sides, we get

$$
\log \frac{\mathrm{Y}}{1-\mathrm{Y}}=\log \mathrm{K}_{\mathrm{b}}+\mathrm{n} \log [\mathrm{M}]
$$

A plot of the left-hand side of Equation S6 versus $\log [\mathrm{M}]$ is known as a Hill plot. It gives an estimate of $\mathrm{n}$ from the slope and $\mathrm{K}_{\mathrm{b}}$ from the ordinate intercept.

We can speculate that the binding of the metal nanoparticles and the target molecules in cells results in cell death. Then the concentration of the $\mathrm{TM}_{\mathrm{n}}$ complexes is directly proportional to the relative cell mortality. If we denote the number of cells at no exposure to metal nanoparticles as $\mathrm{N}$ and the number of dead cells at the metal nanoparticles of concentration [M] as $N_{d}$, then the relative cell mortality $(D)$ is equal to the following:

$$
D=\frac{N}{N_{d}}
$$

Similarly, the relative cell viability $(V)$ is equal to:

$$
V=\frac{N}{N_{v}},
$$

where $N_{v}$ is the number of the viable cells at the metal nanoparticles of concentration [M].

From Equations S4, S7, and S8, it is inferred that Equation $\mathrm{S} 6$ can be presented as follows:

$$
\log \frac{\mathrm{Y}}{1-\mathrm{Y}}=\log \frac{1-V}{V}=\log \mathrm{K}_{\mathrm{b}}+\operatorname{nlog}[\mathrm{M}]
$$

where $\mathrm{V}$ is the relative cell viability measured by the cell viability assay. 
Thus, the measurements of the cell viability as a function of the concentration of metal nanoparticles yield values of the association constant and the valence of the binding of metal nanoparticles and the cell target molecules.

\section{Zeta potential}

Zeta potentials were calculated with Henry's equation:

$$
\zeta=3 \eta \mu / 2 \varepsilon \mathrm{F}(k \alpha)
$$

in which $\zeta$ is the zeta potential, $\eta$ is the viscosity, $\mu$ is the electrophoretic mobility, $\varepsilon$ is the dielectric constant of the medium and $\mathrm{F}(k \alpha)$ is Henry's function, which equals 1.5 using the Smoluchowski approximation. ${ }^{8}$

\section{Disclaimer}

Certain commercial equipment, instruments, or materials are identified in this paper to specify the experimental procedure adequately. Such identification is not intended to imply recommendation or endorsement by the National Institute of
Standards and Technology, nor is it intended to imply that the materials or equipment identified are necessarily the best available for the purpose.

\section{References}

1. Tokushige M, Nishikiori T, Ito Y. Plasma-induced cathodic discharge electrolysis to form various metal/alloy nanoparticles. Russ $J$ Electrochem. 2010;46(6):619-626.

2. Kruyt HR. Colloid Science. Vol VI. New York: Elsevier; 1952.

3. Samoylov AM, Samoylova TI, Pustovyy OM, et al. Novel metal clusters isolated from blood are lethal to cancer cells. Cells Tissues Organs. 2005; 179(3):115-124.

4. Vainrub A, Pustovyy O, Vodyanoy V. Resolution of $90 \mathrm{~nm}$ (lambda/5) in an optical transmission microscope with an annular condenser. Opt Lett. 2006;31(19):2855-2857.

5. Berridge MV, Herst PM, Tan AS. Tetrazolium dyes as tools in cell biology: new insights into their cellular reduction. Biotechnol annual review. 2005;11:127-152.

6. Connors KA. Binding Constants: The Measurements of Molecular Complex Stability. New York: John Wiley \& Sons; 1987.

7. Kuchel PW, Ralston GB. Theory and Problems of Bio-chemistry. New York: McGraw-Hill; 1988.

8. Jachimska B, Wasilewska M, and Adamczyk Z. Characterization of Globular Protein Solutions by Dynamic Light Scattering, Electrophoretic Mobility, and Viscosity Measurements. Langmuir. 2008;24:6866-6872.

\section{Publish your work in this journal}

The International Journal of Nanomedicine is an international, peerreviewed journal focusing on the application of nanotechnology in diagnostics, therapeutics, and drug delivery systems throughout the biomedical field. This journal is indexed on PubMed Central, MedLine, CAS, SciSearch $\AA$, Current Contents ${ }^{\circledR} /$ Clinical Medicine,
Journal Citation Reports/Science Edition, EMBase, Scopus and the Elsevier Bibliographic databases. The manuscript management system is completely online and includes a very quick and fair peer-review system, which is all easy to use. Visit http://www.dovepress.com/ testimonials.php to read real quotes from published authors. 